\title{
Congenital Malformation of the Skeleton in Weiser-Maples Guinea Pigs
}

\author{
Tomoyuki INABA and Yoshikuni WAKISAKA \\ Shiseido Co., Ltd., Safety and Analytical Research Center, 1050 Nippa-cho, \\ Kohoku-ku, Yokohama-shi, Kanagawa 223, Japan
}

(Received 30 July 1991/Accepted 17 December 1991)

\begin{abstract}
Some abnormalities were observed in the occipital bone, cervical vertebrae and thoracic vertebrae of Weiser-Maples guinea pigs. In the occipital bone, the medial basilar impression was suggested to occur in $40(32.8 \%)$ out of 122 animals. The basilar impression was classified into right, left and both side types and observed in 24,11 and 5 animals, respectively. The basilar impression was known to be accompanied in human with some anomalies such as platybasia, Klippel-Feil syndrome, deformation of foramen magnum and so on. These anomalies were also observed in guinea pigs. The fusion of the axis with the $3 \mathrm{rd}$ cervical vertebra was observed in $12(10.5 \%)$ out of 114 animals. The deformation was sometimes observed in the temporal, interparietal, atlas and axis as well as the occipital bone. The fusion of the 7 th cervical vertebra with the 1 st thoracic vertebra was found in $46(51.7 \%)$ out of 89 animals. This fusion was thought to have no relation with the basilar impression. Weiser-Maples guinea pigs are now in 19 generations of sibmating. Because these abnormalities as mentioned above are all thought to be inherited, the selective breeding will make Weiser-Maples guinea pigs suitable for the study of the basilar impression. - KEY WORDS : basilar impression, congenital malformation, guinea pigs, Klippel-Feil syndrome
\end{abstract}

\section{Weiser-Maples 系モルモットの骨格異常}

\author{
稲葉智之・脇坂美国
}

株式会社資生堂安全性分析センター

\footnotetext{
後頭骨から頸椎にかけての発生過程は複雑であり, 最 も遅れて神経管が閉鎖するこの部位は，脳・脊䯣と頭蓋 及び脊椎の生長に違いを生じた場合に異常を起こしやす い。さらに, この部位は解剖学的に頭部の重量を支える 部位であることからも変形を生じる可能性が高く, ヒト では大孔付近の異常に関する報告が比較的多く認められ るという $[17,18]$ 。しかし，実験動物を含む獣医学領域 では，大孔付近の自然発生的骨格異常の報告は少なく， イヌにおいて大孔が背方へ切れ込む異常 $[1,14,15]$, 頸 椎の異常による脊酭圧迫 [13] の報告が認められる程度 である。
}

われわれはこれれで Weiser-Maples 系モルモット を維持継代しながら各種データを集めてきたが，今回， 形態計測学的データを使用した系統間の判別分析 $[4,5]$ を行らため, Weiser-Maples 系モルモット頭部の骨晒 し標本を作成したところ, 大孔の形態異常を呈する個体 が発見された。モルモットの大孔付近の骨に見られる異 常発生の形態に関する報告は，これまでなされていない ため, 本研究では, 頭部から頸・胸部にかけて認められ たモルモットの骨格異常とその発生率について検討を行 った。 


\section{材料および方法}

使用動物：当研究所において兄妹交配により維持して いる Weiser-Maples 系モルモット（近交世代数：12〜

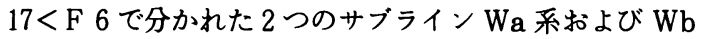
系>, 㞍し交配世代数: $8 \sim 9<\mathrm{Whr}$ 采, サブライン $\mathrm{Wa}$ 系の世代更新と共にへアレス遺伝子を導入している 系統〉）の０８4週龄の倠 43, 雄 74, 不明 5 の計 122例 を用いた。また，比較のためにクローズドコロニー化し て 2 年程度である国立予防衛生研究所由来の JY-1 系乇 ルモットの雄17例, 日本エスェルシー社のハートレイ系 クリーンモルモットの雌107, 雄 4 の計111例及び別施設 で生産された WM 系モルモット（クローズドコロニー の Weiser-Maples 系) の雌13，雄16の計29例を，それ ぞれ約 4 週路にて当研究所に導入し, JY-1系モルモット は25週龄，ハートレイ系モルモットは12〜13週龄，WM 系モルモットは25〜36週龄まで飼育した後使用した。

飼育条件：動物は12時間明, 12時間暗の照明下で, 温 度20 26 ${ }^{\circ}$ C, 湿度 40 7096の飼育室において網床のヶー ジを使用して飼育した。飼料は，モルモット・ウサギ飼 育用固形飼料（オリエンタル酵母工業社製，RC 4）を不 断給与した。领料水は, ミクロフィルター処理後, 紫外 線殺菌した水道水を, 自動給水装置により自由に撕取さ せた。

標本作製：動物は炭酸ガスを使用して安楽死させた 後, 頸部を含む頭部全体を採取した。頭部は後藤らの方 法 [5] に準じオートクレーブ処理後物理的に処理し, 0.5\%のパパイン処理を追加した。漂白のためには過酸 化水素水処理を行い, 脱脂不完全なものはェタノールに
浸漬後自然軲燥し, 観察用標本とした。標本は, 頭骨の み，上位頸椎まで及び胸椎までのものが得られた。ま た, 一部の例では $60 \mathrm{kvp}, 20 \mathrm{~mA}$, 距離 $80 \mathrm{~cm}$, 露出時間 $0.06 \mathrm{~s}$ の条件で，無麻酔下のレントゲン撮影を行った。

形態計測 : 異常発生率の比較をサブライン間で行うた め, Weiser-Maples 系モルモット下頼骨の写真撮影し たものを用い，後藤らの方法 [5] に準じた部位（Figs. 1，2）を計測し，パーソナルコンピュータを使用した市 販の統計ソフト（多変量解析プログラム, 日本マイコン 販売株式会社）により判別分析を行った。

統計処理 : 異常の発生に関する検定には累積カイ 2 乗 検定あるいは Fisher の直接確率計算法を用い, 有意水 準は $5 \%$ とした。

\section{成 縤}

1. 大孔の異常 : 検查した Weiser-Maples 系モルモ ット122例，JY-1系モルモット17例，ハートレイ系モル モット111例，WM系モルモット29例のらち，それぞれ 40例， 0 例， 2 例， 3 例で大孔の異常が認められた (Figs. 3, 4)。

見られた異常は, 後頭顆の位置異常による大孔の不整 形化と後頭骨のねじれであり, 後頭顆の位置異常を示す 側では，側頭骨岩様部の錐体から乳様部にわたる形成不 良により，後頭骨の後方への突出が低下して，左右の対 称性が失われ，端から後頭骨後端までの距離が短縮し ていた（Fig. 5)。また，後頭顆が大孔の中心方向へ陥 入した側の舌下神経孔は，狭窄し，正常側の舌下神経孔 が複数の小孔を伴な5例もみられた（Fig.6）が，両側 性のものでは, 舌下神経孔の異常は認められなかった。

Table 1. Age relationship of foramen magnum deformation and fusion of vertebrae in Weiser-Maples guinea pigs

\begin{tabular}{lccccc}
\hline \multicolumn{1}{c}{ Age (week) } & $0-10$ & $11-20$ & $21-30$ & $31-$ & Total \\
\hline Foramen magnum & $3 / 19$ & $18 / 48$ & $7 / 25$ & $12 / 30$ & $40 / 122$ \\
deformation & $15.8 \%$ & $37.5 \%$ & $28.0 \%$ & $40.0 \%$ & $32.8 \%$ \\
\hline $\begin{array}{l}\text { Fusion of axis } \\
\text { with 3rd cervical } \\
\text { vertebra }\end{array}$ & $1 / 18$ & $5 / 47$ & $4 / 21$ & $2 / 28$ & $12 / 114$ \\
\hline $\begin{array}{l}\text { Fusion of 7th } \\
\text { cervical with 1st } \\
\text { thoracical vertebrae }\end{array}$ & $5.6 \%$ & $10.6 \%$ & $19.0 \%$ & $7.1 \%$ & $9.0 \%$ \\
\hline
\end{tabular}


このよ5な側頭骨の低形成, 舌下神経孔の狭窄, 舌下神 経孔の分裂は, 大孔異常のない個体でも数例で認められ た。さらに，頭頂間骨の矢状稜にねじれを生じているも のも存在した (Fig. 7)。

これらの異常は, Weiser-Maples 系モルモットにお いては 2 週龄程度の若龄から高龄の個体まで $15.8 \%$ 40.0\%の頻度で認められたが，週龄間で異常の発生率に 統計学的な差は認められなかった (Table 1)。さらに, $\mathrm{Wa}$ 系と Wb 系のみをまとめて兄妹交配世代毎に異常 の発生を見ると，16，17世代目が低率であった（Table 2)。また, Weiser-Maples系モルモットにおいて性別 毎に異常の発生を見る（性別不明 5 匹を除外する）と, 雄 74例中 21例 (28.4\%), 倠 43例中 19例 (44.2\%) で, 雙でやや高い傾向にあるが, 統計学的には雌雄間に有意 差は認められなかった（Table 3)。ハートレイ系モル モットでは, 雌 107例中 2 例（1.9\%）で大孔の異常が見
られ, Weiser-Maples 釆モルモットに比較すると低い 発生率であった。

左右どちらの後頭顆が内方へ移動しているかを調べる と, ハートレイ系モルモットでは 2 例とも右側の陥入で あったが，Weiser-Maples系モルモットでは右側性24 例に対し左側性は11例, 両側性のものは 5 例認められた (Fig 8)。また, 右側性の24例中雌は11例, 左側性の11例 中雌は 3 例であり, 両側性の 5 例はすべて雌であった。

下顎骨の形態計測学的データの判別分析により, サブ ライン Wa 系と Wb 系は96.2\%の確率でふたつに分けら れたが, これらのサブライン間で大孔異常の発生に有意 な差は認められなかった。また, コンジェニック系であ るWhr 系及びクローズドュロニーの WM 系においても 低率ではあるが，異常の発生が認められた（Table 4)。

Weiser-Maples 系モルモットで, 親子関係から遺伝 性を見ると，両親に大孔の異常が認められた例において

Table 2. Generation relationship of foramen magnum deformation and fusion of vertebrae in Weiser-Maples guinea pigs

\begin{tabular}{lcccccc}
\hline \multicolumn{1}{c}{ Generation } & 13 & 14 & 15 & 16 & 17 & Total \\
\hline Foramen magnum & $2 / 4$ & $9 / 23$ & $18 / 33$ & $8 / 38$ & $1 / 10$ & $38 / 108$ \\
$\begin{array}{l}\text { deformation } \\
\text { Fusion of axis with }\end{array}$ & $0.0 \%$ & $39.1 \%$ & $54.5 \%$ & $21.1 \%$ & $10.0 \%$ & $35.2 \%$ \\
$\begin{array}{l}\text { 3rd cervical } \\
\text { vertebrae }\end{array}$ & $0.0 \%$ & $9.5 \%$ & $7.1 \%$ & $16.2 \%$ & $20.0 \%$ & $12.0 \%$ \\
\hline $\begin{array}{l}\text { Fusion of 7th } \\
\text { cervical with 1st } \\
\text { thoracical vertebrae }\end{array}$ & $0.0 \%$ & $66.7 \%$ & $28.6 \%$ & $59.5 \%$ & $80.0 \%$ & $56.4 \%$ \\
\hline
\end{tabular}

Table 3. Abnormality rates on sex in three strains of guinea pigs

\begin{tabular}{|c|c|c|c|c|c|c|}
\hline \multirow[b]{2}{*}{ Strain } & \multicolumn{2}{|c|}{$\begin{array}{l}\text { Deformation of } \\
\text { foramen magnum }\end{array}$} & \multicolumn{2}{|c|}{ Fusion of $\mathrm{C} 2-3^{*}$} & \multicolumn{2}{|c|}{ Fusion of $\mathrm{C} 7-\mathrm{T} 1^{*}$} \\
\hline & Male & Female & Male & Female & Male & Female \\
\hline Weiser-Maples & $\begin{array}{l}21 / 74 \\
28.4 \%\end{array}$ & $\begin{array}{l}19 / 43 \\
44.2 \%\end{array}$ & $\begin{array}{l}9 / 66 \\
13.6 \%\end{array}$ & $\begin{array}{l}3 / 43 \\
7.0 \%\end{array}$ & $\begin{array}{c}36 / 52 \\
69.2 \%\end{array}$ & $\begin{array}{c}9 / 32 \\
28.1 \%\end{array}$ \\
\hline JY-1 & $\begin{array}{l}0 / 17 \\
0.0 \%\end{array}$ & - & $\begin{array}{l}0 / 17 \\
0.0 \%\end{array}$ & - & - & - \\
\hline Hartley & $\begin{array}{l}0 / 4 \\
0.0 \%\end{array}$ & $\begin{array}{l}2 / 107 \\
1.9 \%\end{array}$ & $\begin{array}{l}0 / 4 \\
0.0 \%\end{array}$ & $\begin{array}{l}2 / 107 \\
1.9 \%\end{array}$ & $\begin{array}{l}0 / 4 \\
0.0 \%\end{array}$ & $\begin{array}{l}0 / 9 \\
0.0 \%\end{array}$ \\
\hline
\end{tabular}

* : C cervical vertebrae, $\mathrm{T}$ thoracic vertebrae Excluded the unknown sex animals 
Table 4. Abnormality rates in twe sublines, one congenic strain and one closed colony of Weiser-Maples guinea pigs

\begin{tabular}{|c|c|c|c|c|c|c|c|c|c|c|c|c|}
\hline & \multicolumn{4}{|c|}{$\begin{array}{l}\text { Deformation of } \\
\text { foramen magnum }\end{array}$} & \multicolumn{4}{|c|}{ Fusion of $\mathrm{C} 2-3^{*}$} & \multicolumn{4}{|c|}{ Fusion of $\mathrm{C} 7-\mathrm{T}^{*}$} \\
\hline & Wa & $\mathrm{Wb}$ & Whr & WM & $\mathrm{Wa}$ & $\mathrm{Wb}$ & Whr & WM & Wa & $\mathrm{Wb}$ & Whr & WM \\
\hline Normal & 31 & 38 & 13 & 26 & 38 & 50 & 14 & 27 & 7 & 27 & 9 & 23 \\
\hline Abnormal & 15 & 24 & 1 & 3 & 4 & 8 & 0 & 2 & 25 & 19 & 2 & 5 \\
\hline Rate $(\%)$ & 32.6 & 38.7 & 7.1 & 10.3 & 9.5 & 13.8 & 0.0 & 6.9 & 78.1 & 41.3 & 18.2 & 17.9 \\
\hline
\end{tabular}

* : C cervical vertebrae, $\mathrm{T}$ thoracic vertebrae

も子は正常な例があった。

2. 上位頸椎の異常 : 大孔異常の認められた例では, 環椎と軸椎に变形が認められたが, 第 3 頸椎以降には認 められなかった (Figs. 9, 10)。

上位頸椎では, 軸椎と第 3 頸椎の間で疮合が認められ た (Table 3)。ハートレイ系モルモットでは大孔異常 のある 2 例で認められ, そのらちの 1 例では環椎後頭骨 同化及び環椎の背部披裂が認められた（Fig. 11)。頸椎 疮合は, 棘突起, 勒帯及び関節部分での疬合を主体と し, 椎体の疮合は少なく, 椎間板は存在していた。しか し, 椎体瘏合の認められた例では, 疮合の程度が左右で 異なる種々の变形状態を示していた（Fig. 12）。

Weiser-Maples 系モルモットでは，検査できた 114 例中12例 (10.5\%) で軸椎と第 3 頸椎の疮合が認められ た (Table 1)が，そのらちで大孔異常に伴って認められ た病合は 2 例にすぎなかった。さらに，Whr 系モルモ ットでは, 軸椎と第 3 頙椎の痹合は認められなかった。 Weiser-Maples系モルモットの性別毎の異常発生率 を見ると, 雄66例中 9 例 (13.6\%), 倠43例中 3 例 (7.0 96) の発生であり, 雌雄間に統計学的に有意差は認めら れなかった (Table 3)。また, Wa 系と Wb 系間の異常 発生率にも有意差は認められなかった（Table 4)。

3. 下位项椎から胸椎での異常: Weiser-Maples 采 モルモットでは，第 7 頸椎と第 1 胸椎の疮合が検查でき た89例中46例（51.79）に認められた（Table 1)。疮合 は, 軸椎, 第 3 頸椎の間の場合と同様に, 棘突起と関節 部分での疮合が主体であった。椎骨は疮合により短縮 し, 痹合部分は側方からはV字型（Fig. 13）または, 左右方向に“く”の字型を呈する例も認められた（Fig. 14)。週龄每に見ると， 0 週龄から高週龄まで同程度の 変形が見られ, 異常の発生率に週龄間で有意差は認めら れなかった。また，兄妹交配世代毎に見ても，その発生 率に差は認められなかった。性別比較（性別不明 5 例 を除く）では, 雄52例中36例 (69.2\%), 倠32例中 9 例
（28.19）で異常が認められ, 倠雄間に統計学的有意差 が認められた (Table 3)。また，Wa 系と Wb 系間で 比較すると, Wa 系で有意に高い発生率が認められた (Table 4)。しかし, Whr 系の 18.2\%と WM 系の 17.9 \%はほぼ同じ発生率であり，Wb 系よりもさらに低か った。

第 7 頸椎と第 1 胸椎の疮合形成と大孔異常の発生との 関係, あるいは軸椎と第 3 顥椎の恣合形成との間には, 特に相関は認められなかった。

胸椎までの標本が得られたハートレイ系モルモット 13 例では, 第 7 頸椎, 第 1 胸椎間で病合は認められなか ったが, Weiser-Maples 采モルモットに見られない第 2 胸椎棘突起の药合不全が 3 例 (23.1\%) で認められた (Fig. 15)。

\section{考㝓}

大孔の異常は, 後頭顆が大孔内側に傾斜突出して生 じ, 大孔の内側部では鞍状狭窄をきたしていた。この異 常は舌下神経孔の狭窄, 後頭骨以外の側頭骨, 頭頂骨等 の変形を伴っていたため, 後頭顆が大孔内方へ移動し, 側頭骨が低形成となることにより生じた，ヒトの側方型 頭蓋底陥入症に相当すると考えられた。しかし，モルモ ットの頭蓋底はもともと扁平であることから, 扁平頭蓋 底および頭蓋底陥入症の判定にヒトの基準をそのまま当 てはめることは困難である。そこで，モルモットにおけ る判定基隼としては, 脳頭蓋 (頭蓋腔) の球形化, つま り鞍結節付近の下方への突出, 蝶形骨と後頭骨底部の作 る角度の鋭角化をもって扁平頭蓋底様変化と判断した。 この判定基準によると, Weiser-Maples 系モルモット の両側性頭蓋底陥入症は, 扁平頭蓋底様の変化を伴って いると考えられた。

ウサギに扎いては，耳曲がりと斜頸，側頭骨鼓室部の 形状について調べられており，側頭骨鼓室部の骨性耳管 
に生じた位㯰異常による頭蓋骨の変形が報告されている [12] が, Weiser-Maples 系モルモットでは, 側頭骨鼓 室部の異常は認められなかった。

モルモットの先天性奇形の発生等に関しては, いくつ かの報告 $[3,20,22,23,24]$ はあるものの, 今回報告し たような部位における異常発生は, Robens [16] の全頸 椎痣合 1 例の報告が認められるのみであった。

佐野［18］によれば，ヒトの頭蓋底陥入症に関連する 奇形として, 大孔および環椎の狭窄・変形, 環椎後頭骨 同化, アーノルドキアリ奇形, 扁平頭蓋底, 先天性頸椎 疮合症等があげられているが，今回のモルモットの頭蓋 底陥入症に拈いても，ヒトと同様のこれらの関連奇形が 認められた。そのらち，環椎後頭骨同化がみられたハー トレイ系モルモットの 1 例では, 環椎と後頭骨が腹側部 分で瘾合し，環椎には背部披裂があり，大孔には変形と 若干の払大が見られた。そのため，この例では，佐野に よる分類でB型 [17] とされる，アーノルドキアリ奇形 の生じていたことが考えられた。

先天性頸椎疹合症は，広義には 2 個以上の頸椎が癒合 しているものとされ，特に軸椎と第 3 頸椎の間で発生頻 度が高いといわれている $[2,18]$ 。Weiser-Maples 系モ ルモットでは, 頭蓋底陥入症を伴った軸椎と第 3 頸椎の 疮合は少なかったため, 先生性頸椎疬合症が頭蓋底陥入 症の関連奇形とは考えにくい。しかし，ハートレイ系モ ルモットでは軸椎と第 3 頸椎の疮合が大孔異常に関連し て認められたため，モルモットであヒトと同様に，先天 性頸椎疮合症は頭蓋底陥入症に関連した奇形として発生 するものと考えられた。

Weiser-Maples 系モルモットでは，第 7 頸椎と第 1 胸椎の癋合が高率に認められた。この部位では一般に頸 椎の胸椎化等の変異が知られており, 頸肋の発生はラ ット等で報告されている $[10,20]$ 。一方，マウスに拉い てはX線照射により，胸腰椎域の前方推移（第13肋骨久 損) や後方推移（第 1 腰胁骨の存在）等の奇形発生が認 められ，外後頭骨骨核と環椎の瘉合は生ずることすある が, 頸椎と胸椎の境界は変化をらけないという［11］。 そのため, Weiser-Maples 系モルモットで認められた 第 7 頸椎と第 1 胸椎の疮合は, 発生頻度が高いこと, 大 孔と上部頸椎の異常に関連していないこと, 雄で発生頻 度が高く性差が存在することなどを考虑すると，大孔付 近の骨異常とは別の原因によるものと思われた。

週龄間で異常の発生率を見ると, 変動は有るもののほ ぼ一定した値を示していることから，生死に影響するよ らな異常ではなく，加龄変化でもないと考えられた。ま た，近交世代毎に異常の発生率を比較すると，大孔の異
常は近交16，17世代で低く，近交度の上昇とともに減少 する傾向にあると考えられた。

そのため, モルモットでは, 栄養要求量 $[9,21]$ でさ え不明な部分が多いため, 本コロニ一内の環境因子によ り異常が発生していたとも考えられたが，異なった環境 下で繁殖した WM 系モルモットにおいても低率ながら 異常が認められ，環境因子及び栄養因子の影穓は少ない あのと考えられた。なた Weiser-Maples 系モルモッ トはハートレイ系モルモット及び JY-1 系モルモットに 比べ高い異常発生率を示し, 進行性の異常ですないこと から遺伝因子の関与が強く疑われる。しかし，大孔異常 の両親から正常な子が生まれることがあり，大孔の異常 発生に関する遗伝様式は不明であることから，異常同士 の交配を重ねていくことにより遺伝性に関しての検討も 可能となると考えられた。

さらに, Wa 系の世代更新と共に戻し交配を重ねた Whr 系は骨異常の発生が低く, Weiser-Maples 系モル モットのコンジェニック系統としてまだ確立できていな いと判断される結果であった。

ヒトでは神経系等の臨床症状が生じた後にこれらの

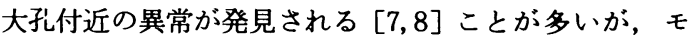
ルモットでは, 頭蓋底陥入症の臨床症状として報告され ている頸部の運動制限, 短頸, 傾斜頭位等の臨床症状等 は認められなかった。さらに，上位頸椎に認められた変 形は, 後頭顆の一側への移動による大孔部分でのねじれ を修正するためではないかと考えられ，イヌで報告され ている脊髄圧迫による障害 $[6,13]$ は認めなかった。

今後, 骨格異常の認められる個体に, 臨床症状が認め られない点に関しては，検査方法を含め検討が必要と考 えられる。

さらに，ハートレイ系モルモットでのみ高率に認めら れた胸椎棘突起の疹合不全は，馬で胎生期に左右にでき た棘突起がしばしば二次瘉合せず分裂した棘突起となる といら報告 [19] ああることから, 大孔の変形及び椎骨 疮合とは別の異常と考えられた。

Weiser-Maples 系モルモットは現在兄妹交配が最高 19世代となっていることから，今後選抜目標を骨異常と することにより，大孔付近の異常の研究に有用な実験動 物となることが期待される。

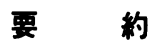

Weiser-Maples 系モルモットの後頭骨から胸椎にか けていくつかの異常が認められた。後頭骨では, 側方型 頭蓋底陥入症と考えられる変形を122例中40例 (32.8\%) 
に認めた。そのうち右側性24例, 左側性11例, 両側性 5 例であった。ヒトの頭蓋底陥入症に関連する奇形として 知られている, 大孔及び環椎の狭窄 - 変形, 扁平頭蓋 底, 先天性頸椎痣合子認められ, 軸椎, 第 3 頸椎間の疮 合は 114例中 12例 (10.5\%) であった。また, 骨の変形 は後頭骨以外に, 頭頂間骨, 側頭骨, 環椎, 軸椎にも及 んでいた。第 7 頸椎と第 1 胸椎間の疮合形成が89例中46 例（51.7\%）と高率に見られた。しかし，この部位の痣 合は，軸椎，第 3 頸椎間の癒合形成とは異なった原因に より生じていることが考えられた。これらの奇形は遺伝 性疾患と考えられることから，選抜交配を行っていくこ とにより Weiser-Maples 系モルモットは大孔付近の異 常の研究に有用な実験動物となることが期待される。

\section{文献}

[1] Bardens, J. W. (1965). Congenital malformation of the foramen magnum in dogs. Southwest. Vet., 18, 295-298.

[2] Festing, M. F. W. (1974). Some biological data on guinea-pigs. $G P N L, 8,5-15$.

[3] Festing, M. F. W. (1978). Congenital abnormalities in guinea-pigs. $G P N L, 13,11-15$.

[4] Festing, M. F. W. (1979). Skeletal morphology. In Inbred Strains in Biomedical Research, pp. 48-51, Festing, M. F. W. (ed.), The Macmillan Press, London.

[5] Goto, N, Watanabe, K., Umezawa, H., Yazawa, H., and Kuramasu S. (1987). Morphometrical observations on the mandible of five strains of rabbits and strain identification using mandible measurements. Lab. Anim, 21, 188-194

［6］川村清市（1983）. ウオブラ症候群．主要症状を基礎に した犬の臨床，pp. 606-508，其田三夫監修，デーリィマ ソ社, 東京。

[7] Kruyff, E. and Jeffs, R. (1966). Skull abnormalities associated with the Arnold Chiari malformation. Acta Radia, 5, 9-21.

[8] McRae, D. L. (1952). Bony abnormalities in the region of the foramen magnum : Correlation of the anatomic and neurologic findings. Acta Radiol, 40, $335-354$.

[9] National Research Council (1978). Nutrient requirements of the guinea pig. In Nutrient Requirements of Laboratory Animals, 3 rd ed., pp. 59-69, National Academy of Sciences, Washington DC.

[10] Morita, H., Ariyuki, F., Inomata, N., Nishimura, K., Hasegawa, Y, Miyamoto, M., and Watanabe, T. (1987). Spontaneous malformations in laboratory animals : Frequency of external, internal and skeletal malformations in rats, rabbits and mice. Cong. Anom, 27, 147-206.

［11］村上氏廣（1976）. 物理的要因によるもの．出生前の医 学, pp. 295-319, 村上氏廣・馬場一雄・鉿木雅洲煸，医 学書院, 東京。

［12］太田 栄・遠近敏文・大西絧一・浜田佑二・岡田忠夫 (1990).ウサギの耳まがりと斜钼との関係について．実 験動物技術, 25, 130-132

[13] Palmer, A., Margaret, C., and Wallance, E. (1967). Deformation of cervical vertebrae in baset hounds. Vet. Rec., 80, 430-433.

[14] Parker, A. J. and Richard, D. P. (1974). An unusual case of occipital dysplasia in the dog. V.M.SA C. $69,438-440$.

[15] Parker, A. J. and Richard, D. P. (1974). Occipital dysplagia in the dog. J. Am Anim Hosp. Assoc., 10, 520-525

[16] Robens, J. F. (1969). Teratologic studies of carbaryl, diazinon, norea, disulfiram, and thiram in small laboratory animals. Toxicol Appl Phamacol, 15, 152-163

［17］佐野圭司－千ヶ崎裕夫（1964）。水頭症と Arnold-Chiari 奇形. 神経進歩, 8, 241-262

［18］佐野圭司・名和田宏（1964）。頭蓋底陥入症および大孔 の骨異常. 神経進歩，8，263-287。

[19］佐藤幸雄 (1967). 骨の発生. 家畜の発生・解剖要説, pp. 174-195. 学空社, 東京.

［20］谷村 孝（1989）. 自然発生異常（奇形など）に関する データ. 実験動物の生物学的特性データ, pp. 399-444, 田嶋嘉雄監修，ソフトサイエンス社，東京。

[21] 土田孝雄 (1990)。モルモットに関寸る飼料栄養研究動 向について. アニテックス, 2, 69-74.

[22] Wright, S. (1922). The effects of inbreeding and crossbreeding on guinea pigs. US Dept. Agr. Tech Bull, 1090, 1-63.

[23] Wright, S. and Wagner, K. (1934). Types of subnormal development of the head from inbred strains of guinea pigs and their bearing on the classification and interpretation of vertebrae monsters. Am $J$ Anat., 54, 383-447.

[24] Wright, S. (1960). The gnetics of vital characters of the guinea pig. J. Cell Comp. Physiol, 56, 123151. 


\section{Explanation of Figures}

Fig. 1. Mandible of a Weiser-Maples guinea pig

Fig. 2. Measurements taken on mandible of guinea pigs

Fig. 3. Deformation of foramen magnum in a male Weiser-Maples guinea pig (left side type, a left occipital condyle was moved for upper and inside)

Fig. 4. Anterior-posterior radiographs of foramen magnum in Weiser-Maples guinea pigs Arrow : impression site (left : normal right : right side type basilar impression)

Fig. 5. Occipital impression in a Weiser - Maples guinea pig (left side type basilar impression) Arrow : deformation site of the temporal bone

Fig. 6. The condyloid canals of Weiser - Maples guinea pigs A : Left normal condyloid canal in the right side type basilar impression $\mathrm{B}:$ Right restricted condyloid canal in the right side type basilar impression $\mathrm{C}$ : Hyperplasia of condyloid canal in the left side type basilar impression

Fig. 7. Inclination of sagittal crest with the right side type basilar impression in a WeiserMaples guinea pig Arrow : sagittal crest

Fig. 8. Foramen magnum and occipital condyles in Weiser-Maples guinea pigs, (left : both side type basilar impression with platybasia, both side occipital condyles were moved for inside and foramen magnum is not seen circle, right : right side type basilar impression butf oramen magnum is seen like mormal)

Fig. 9. Cranial aspect of the torsive atlas with basilar impresson in a Weiser-Maples guinea pig (deformed for match the occipital condyles in basilar impression)

Fig. 10. Inclination of the axis spinous process and the normal cervical vertebrae after the 3 rd cervical vertebra in a Weiser-Maples guinea pig Arrow : the axis spinous process

Fig. 11. Occipitalization and rachischisis of the atlas in a Hartley guinea pig Arrow : rachischisis site

Fig. 12. Fusion of the axis with the 3 rd cervical vertebra in a Weiser-Maples guinea pig (Klippel-Feil syndrome, Type 2) Arrow : fusion site

Fig. 13. Inclinative vertebrae in Weiser-Maples guinea pigs (upper : fusion of the 7 th cervical vertebra with the lst thoracic vertebra, lower: nomal) Arrows : the 6th cervical vertebra

Fig. 14. Inclinative vertebrae in a Weiser-Maples guinea pig (fusion of the 7 th cervical vertebra with the 1 st thoracic vertebra) Arrow : the 6 th cervical vertebra

Fig. 15. Thoracispinal spondyloschisis of the 2 nd thoracical vertebra in a Hartley guinea pig (it is seen with the 7th cervispinal spondyloschisis) Arrows : the spondyolschisis site 


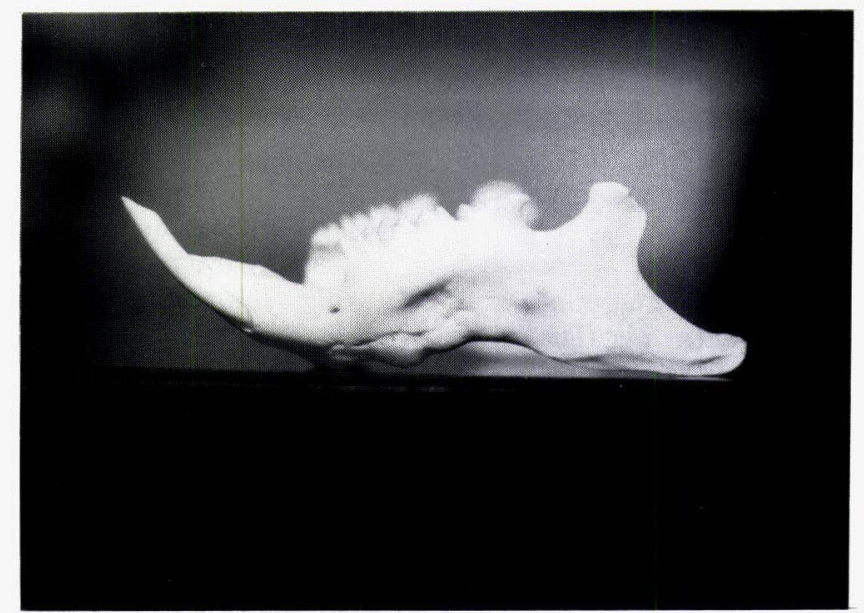

Fig. 1.

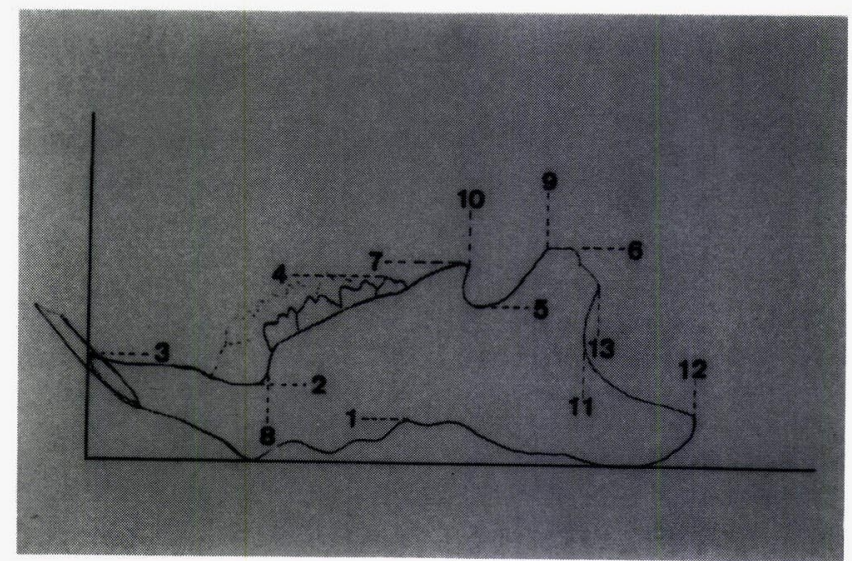

Fig. 2.

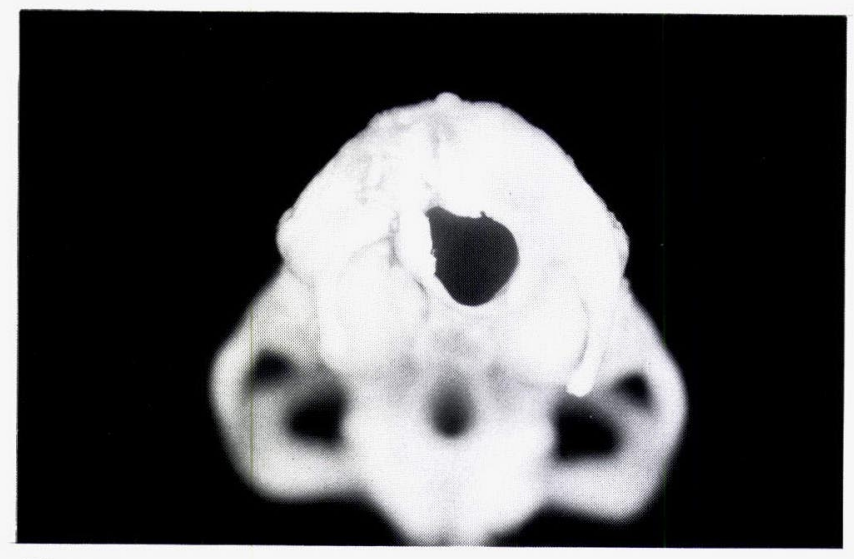

Fig. 3. 


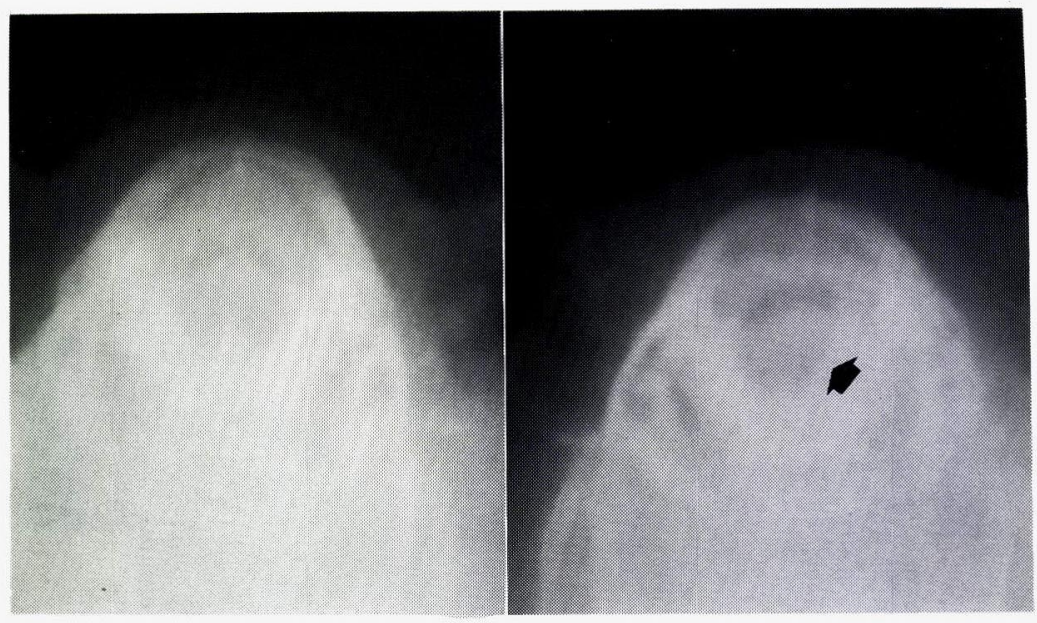

Fig. 4.

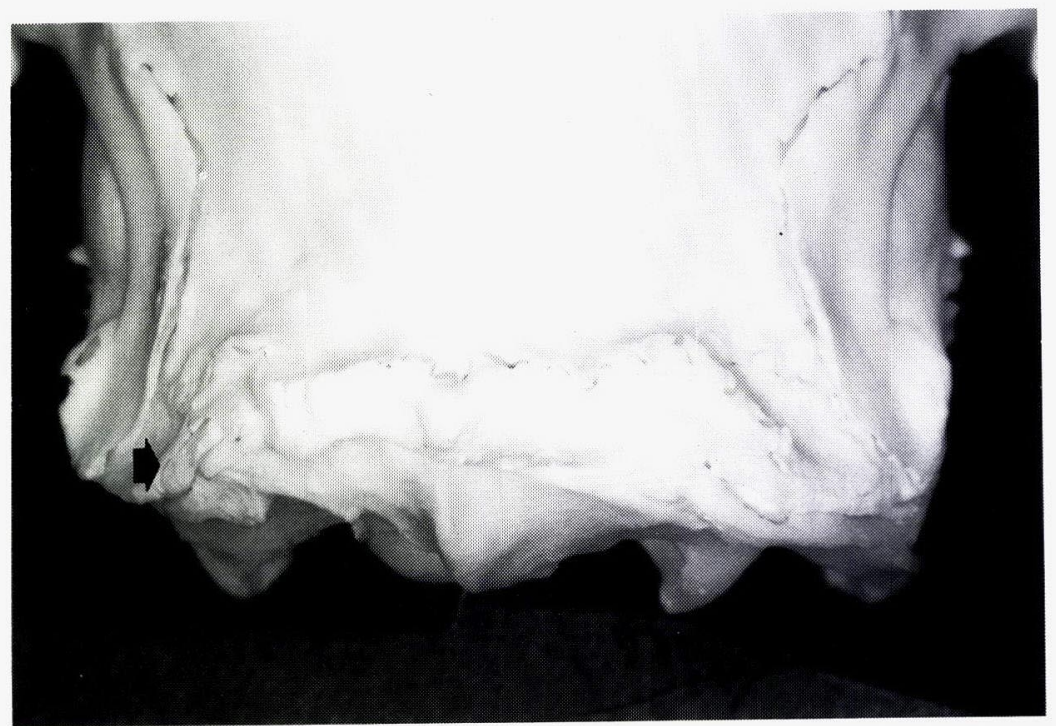

Fig. 5. 


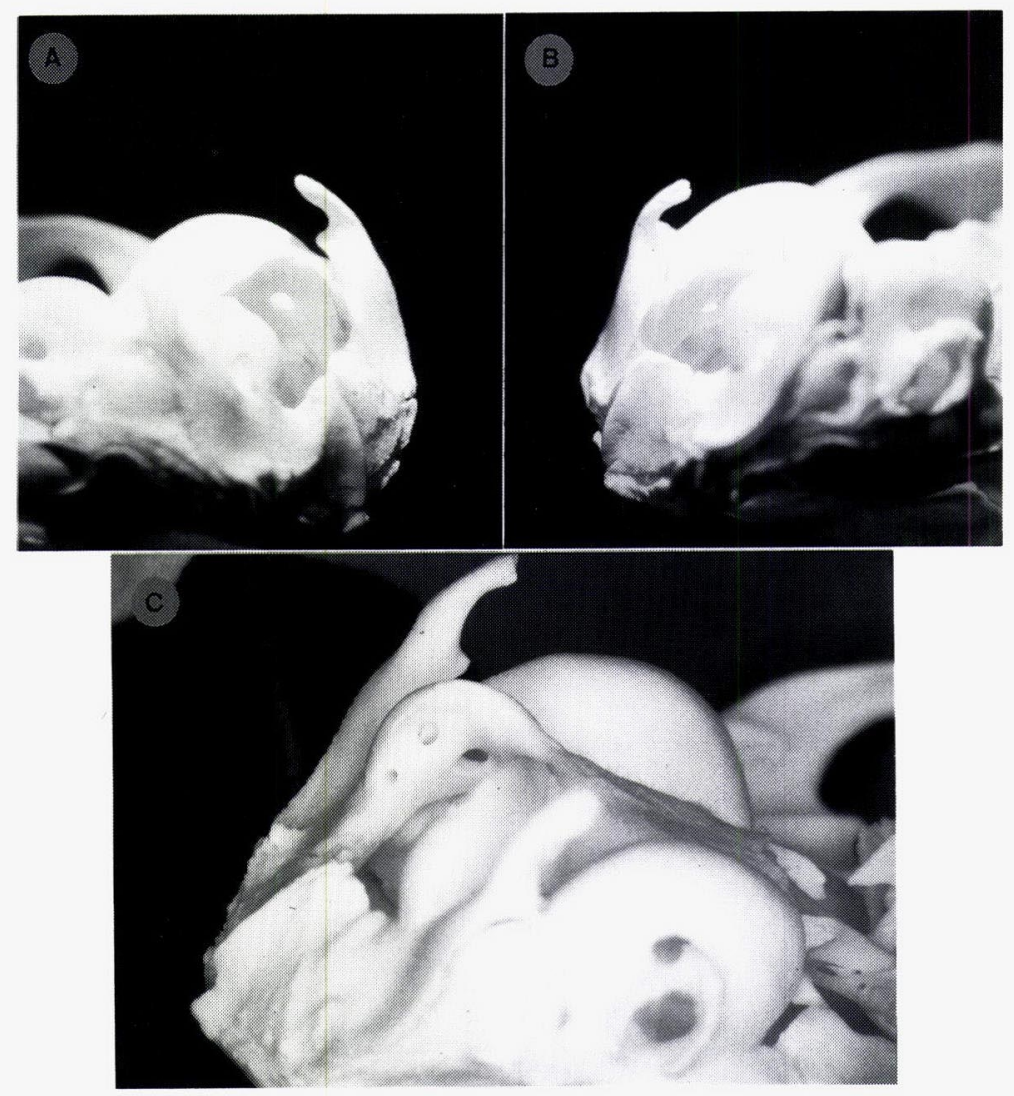

Fig. 6.

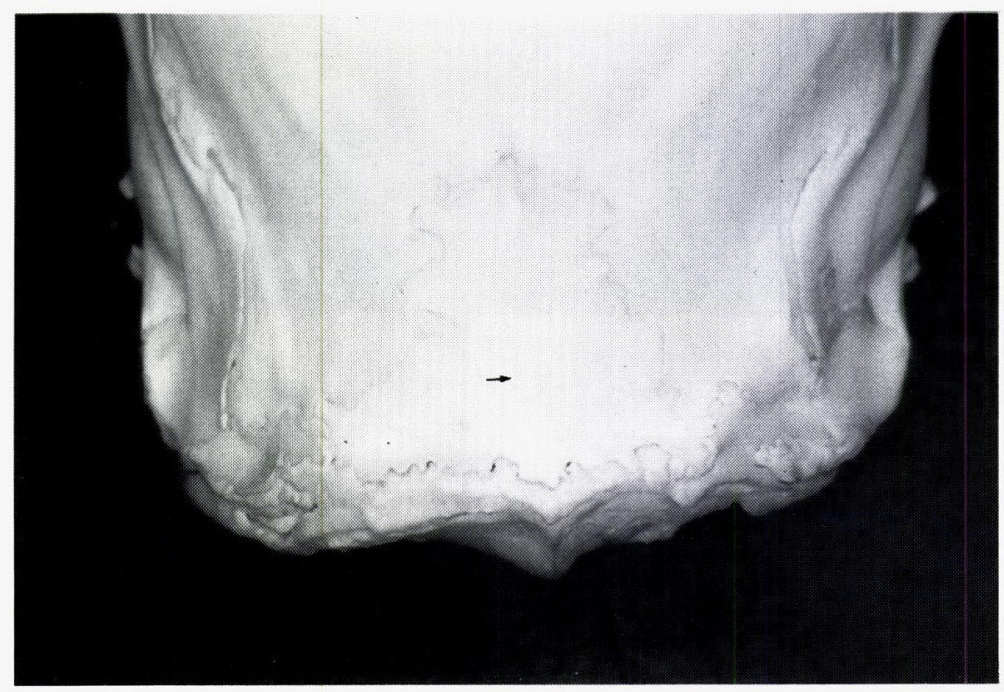

Fig. 7. 


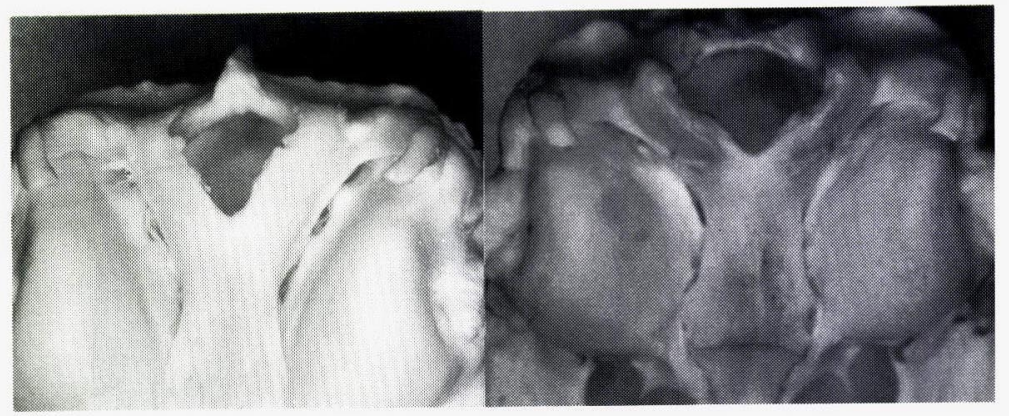

Fig. 8.

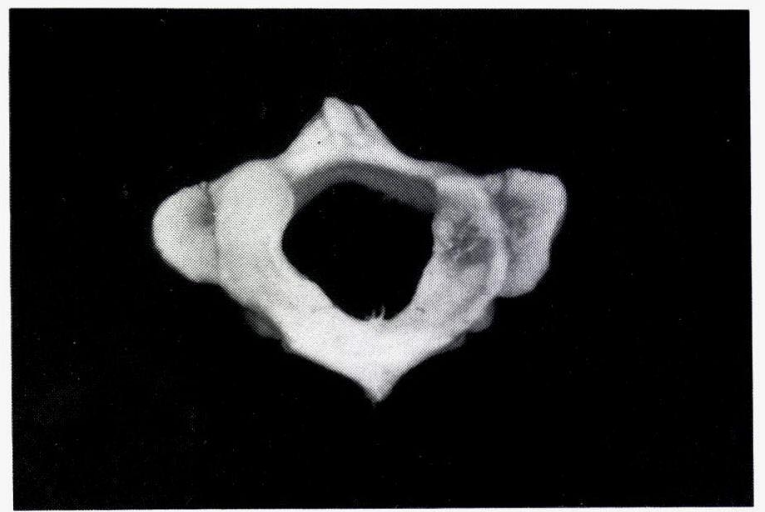

Fig. 9.

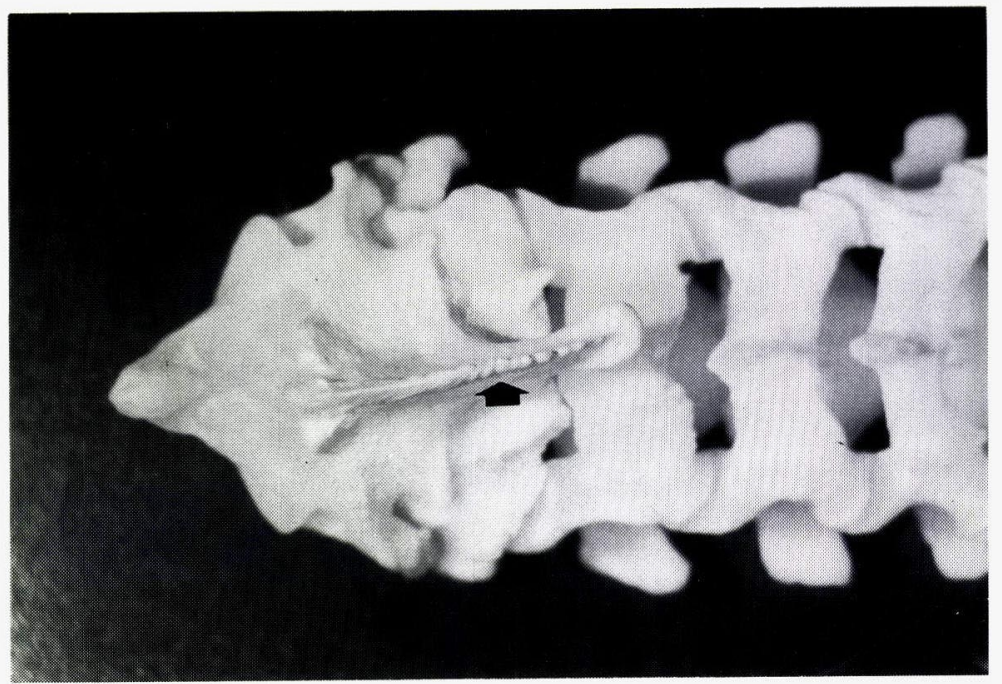

Fig, 10. 


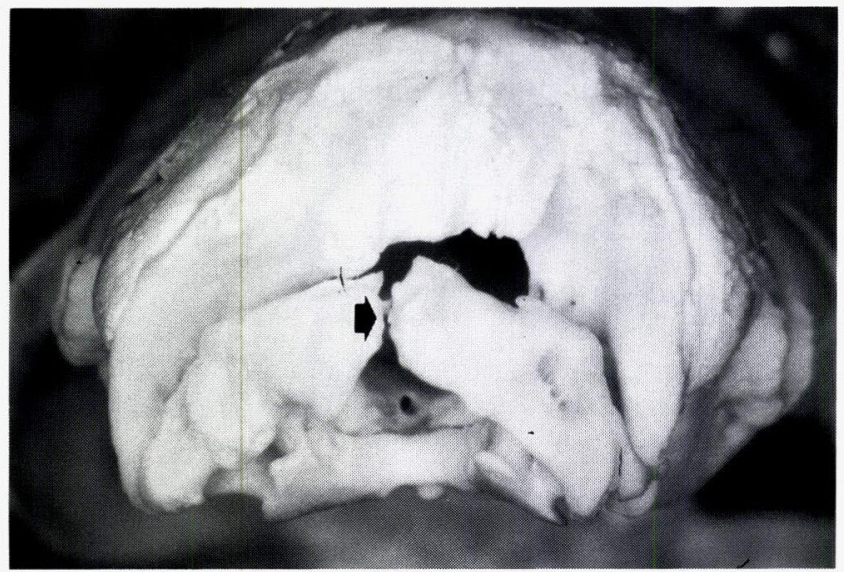

Fig. 11.

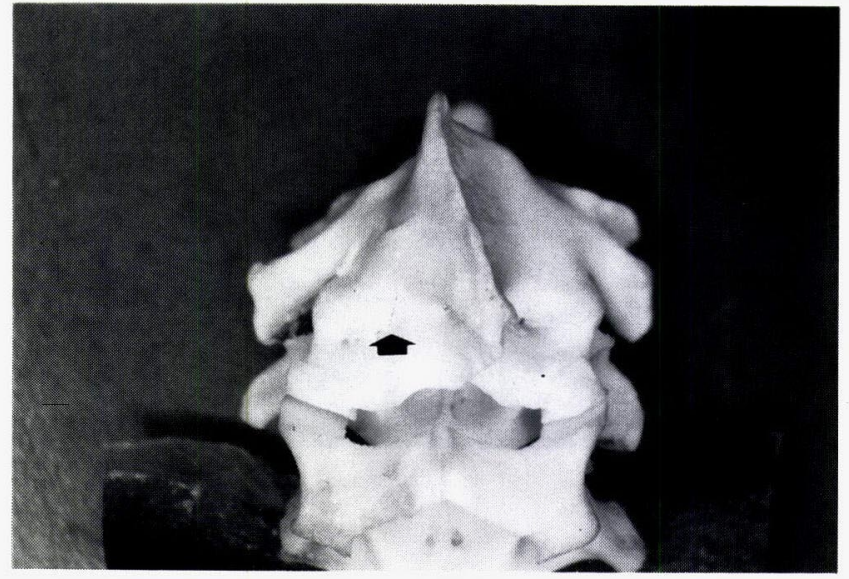

Fig. 12.

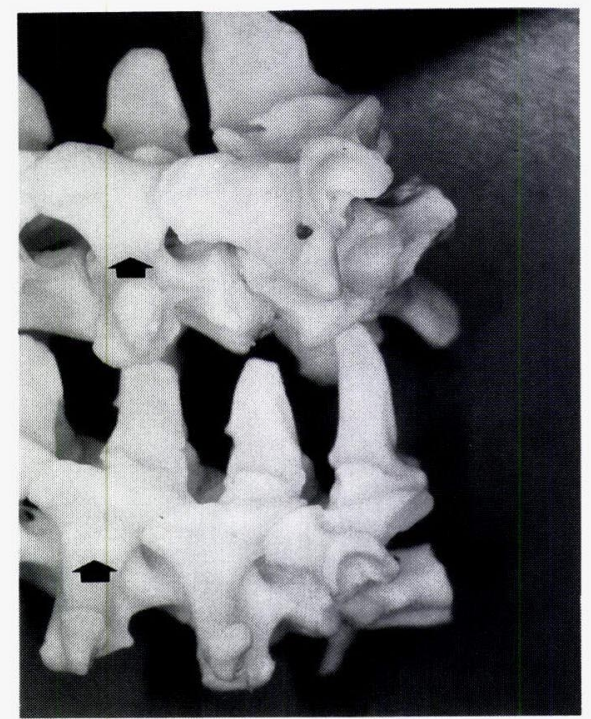

Fig. 13. 


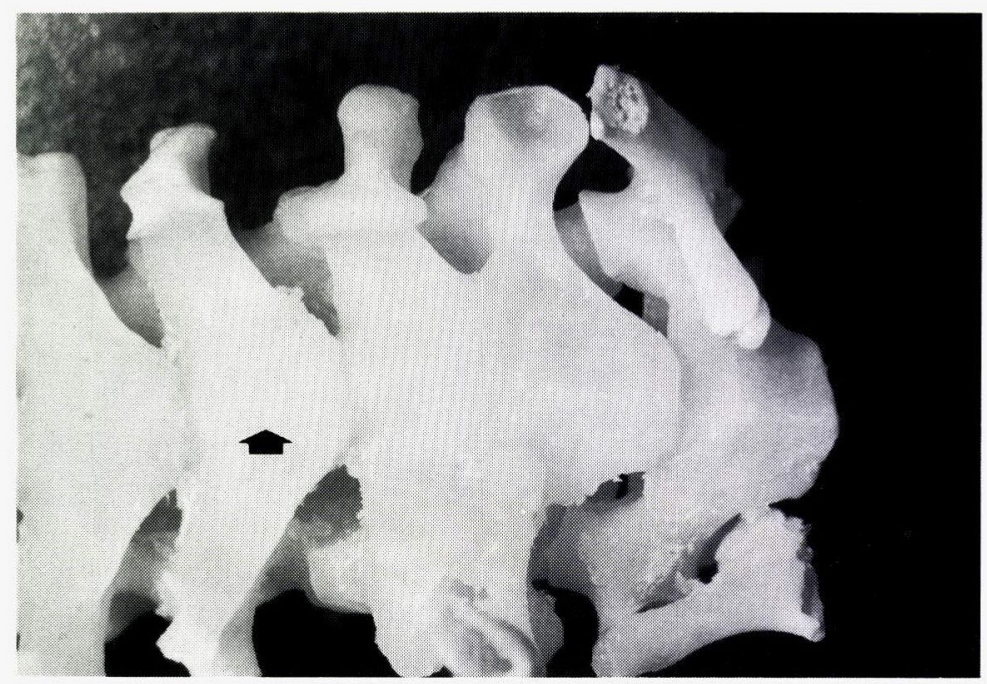

Fig. 14.

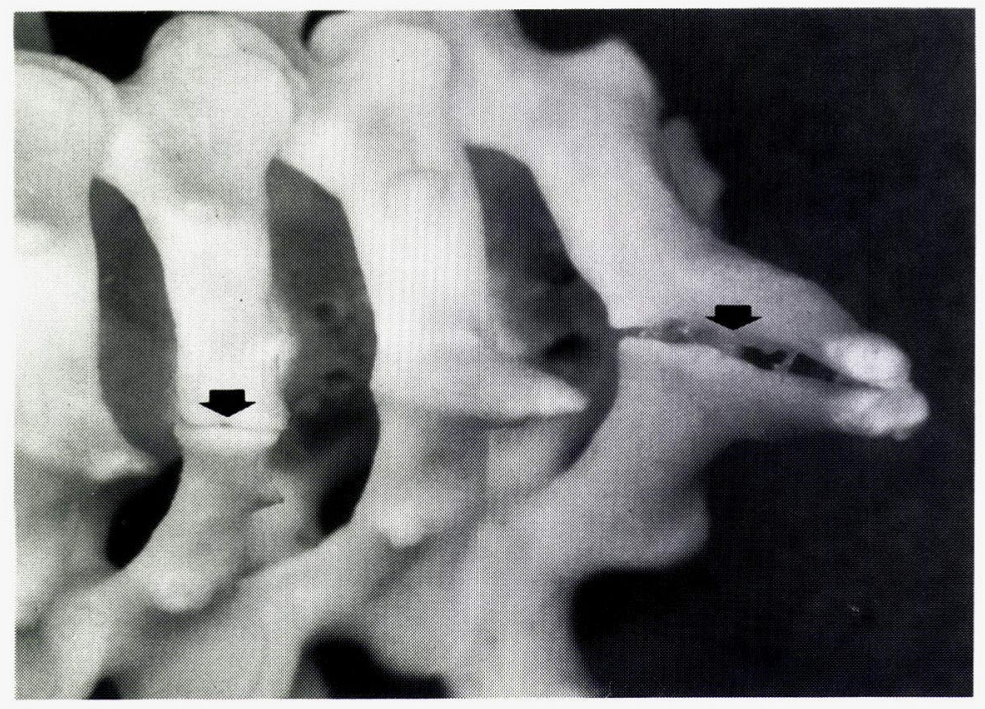

Fig. 15. 